\title{
Література
}

1. Бахтин М. М. Вопросы литературы и эстетики. - М.: Художественная литература, 1975. 504 с. 2. Гадамер Х.- Г. Истина и метод: основы философской герменевтики / Общая ред. и вступ. статья Б. И. Бессонова. - М.: Прогресс, 1988. - 704 с. 3. Балл Г.О. Сучасний гуманізм і освіта: соціально-філософські та психолого-педагогічні аспекти. - Рівне: «Ліста-М». - 2003. - 128 с. 4. Барт Р. Избранные работы. Семиотика. Поэтика. - М.: Издательская группа «Прогресс», «Универс», 1994. - 464 с. 5. Боришевский М. Й. Духовні цінності як детермінанта розвитку та саморозвитку особистості // Психолого-педагогічні засади розвитку особистості в освітньому просторі: Матеріали методологічного семінару АПН України 19 березня 2008 р.; за ред. С. Д. Максименка, І. Д. Беха, О. В. Сухомлинської та ін.- К. : Вид-во АПН України, 2008. - 728 с. 6. Боришевский М. Й. Духовність в особистісних вимірах // Проблеми загальної та педагогічної психології: зб. наук. праць Інституту психології ім. Г. С. Костюка АПН України; за ред С. Д. Максименка. - Т. Х. Част. 4. - К. Гнозіс, 2008. - 682 с. 7. Костюк Г. С. Принцип развития в психологии // Методологические и теоретические проблемы психологи; под ред. Е. В. Шороховой. М.: Наука, 1969. - С. 118-152. 8. Максименко С. Д. Основи генетичної психології. - К.: НПЦ Перспектива, 1998. - 220 с. 9. Максименко С. Д. Генезис существования личности. - К.: Изд-во ООО «КММ», 2006. - 240 с. 10. Маноха І. П. Психологія потаємного «Я» / І. П. Маноха. - К. : Поліграфкнига, 2001.- 448 с. 11. Роменець В. А. Вчинок і світ людини // Основи психології: [підручник] / за заг. ред. О. В. Киричука, В. А. Роменця. - Київ: Либідь, 1995. - С. 383-402. 12. Роменець В. А. Вчинок як принцип побудови теорії та історії психології // Основи психології: [підручник] / за заг. ред. О. В. Киричука, В. А. Роменця. - Київ: Либідь, 1995. - С. 161-193. 13. Татенко В. А. Вчинок в онтологічному вимірі // Основи психології: [підручник] / за заг. ред. О. В. Киричука, В. А. Роменця. - Київ: Либідь, 1995. - С. 402-424. 14. Татенко В. А. Психология в субъектном измерении. - К. : Просвита, 1996. - 404 с. 15. Франк С. Л. Реальность и человек / С. Л. Франк. - М. : Республика, 1997. - 479 с. 16. Чепелева Н. В. Теоретические основы психологической герменевтики // Актуальні проблеми психології. Т. 2. Психологічна герменевтика: зб. наук. праць / за ред. Н. В. Чепелєвої. - К., 2001. - Вип. 1. - С. 5-19. 17. Чепелева Н. В. Тенденции и перспективы психологической герменевтики // Практична психологія в контексті культур: зб. наук. праць / відп. ред. З. Г. Кісарчук. -К.: Ніка-центр, 1998. - С. 174-182.

Інна Кондратець

\section{РОЛЬ МОТИВАЦІЙНО-ЦІЛЬОВОГО ЕТАПУ ТЕХНОЛОГЇ̈ ФОРМУВАННЯ РЕФЛЕКСИВНОӤ КУЛЬТУРИ В СИСТЕМІ ПРОФЕСІЙНОГО САМОРОЗВИТКУ ПЕДАГОГІВ}

Кондратець I. В. Роль мотиваційно-цільового етапу технології формування рефлексивної культури в системі професійного саморозвитку педагогів.

Статтю присвячено ролі мотиваційно-цільового етапу технології формування рефлексивної культури в системі професійного саморозвитку педагогів. Розкрито сутність засобів забезпечення мотиваційного етапу, механізму взаємозв'язку між мотивацією та рівнем рефлексивних прагнень, здібностей, умінь і навичок.

Ключові слова: рефлексія, рефлексивна культура, рефлексивні процеси, мотивація, прагнення, саморозвиток.

Кондратец И. В. Роль мотивационно-целевого этапа технологии формирования рефлексивной культуры в системе профессионального саморазвития педагогов.

Статья посвящена роли мотивационно-целевого этапа технологии формирования рефлексивной культуры в системе профессионального саморазвития педагогов. Раскрыта суть методов обеспечения мотивационного этапа, механизма взаимосвязи между мотивацией и уровнем рефлексивных намерений, способностей, умений и навыков.

Ключевые слова: рефлексия, рефлексивная культура, рефлексивные процессы, мотивация, стремления, саморозвитие.

Kondratec I. V. Value of the motivation-having a special purpose stage of technology of forming of reflection culture in the system of professional development of teachers. 
The article is devoted the role of the motivation a special purpose stage of technology of forming of reflection culture in the system of professional development of teachers. Essence of methods of providing is exposed motivation, mechanism of intercommunication between motivation and level of reflection intentions, capabilities, abilities and skills.

Key words: reflection, reflection culture, reflection processes, motivation, aspirations.

Вимоги до педагогічних працівників загальноосвітніх закладів із неминучістю зумовлюють реформування усієї освітньої системи, але в передовсім вони висуваються до особистості педагога, який має відповідати високому рівню професіоналізму. Адже конкретну дитину виховує конкретний педагог, і рівень розвитку кожного вихованця залежатиме від якості професійної підготовленості й майстерності кожного педагога.

При цьому відновлення системи підвищення кваліфікації педагогічних працівників має спиратись на індивідуальні запити розвитку особистості конкретного педагога, іiі акмеологічні аспекти, бути зорієнтованим на перспективні потреби педагога.

Водночас аналіз досвіду реформування системи підвищення кваліфікації і нові задачі, що постають перед нею, надають підстави для внесення істотних коректив до стратегії й тактики їі розвитку, тому що вона залишається недостатньо конкурентоздатною, не забезпечує мобільності програм підготовки, різнорівневість запитів і можливостей педагогів.

Сучасна освітня ситуація потребує від педагога рефлексивності як необхідної професійної якості.

Професійна рефлексія (від лат. «звернення назад») складається з усвідомлення і розуміння усієї структури системи взаємовідносин з усіма суб'єктами освітнього процесу; усвідомлення особливостей взаємовідносин всіх суб'єктів освітнього процесу; усвідомлення міри своєї професійної компетентності, враховуючи рівень знань, а також комунікативних, методичних і загальнопедагогічних умінь та навичок. Адекватне, наскільки це можливо, усвідомлення рівня і характеру різниці між ідеальними образами та реальною ситуацією «Я - у професії», $\epsilon$ стимулом для вдосконалення, особистісного і професійного зростання педагога, у чому і вбачається значення професійної рефлексії.

3 іншого боку, педагог має створити усі умови для формування рефлексивної культури кожного вихованця, тобто спрямувати дитину на пізнання свого внутрішнього світу, розпізнавання почуттів й оволодіння умінням називати їх, розуміння багатоваріативності своєї поведінки і наявності широкої палітри можливостей, навчання брати на себе відповідальність за свої рішення, дії та вчинки, що завжди є свідченням особистісного зростання.

Найвитонченіші прийоми виховання, на думку В. Сухомлинського, $\epsilon$ методично нереалізованими, якщо вони не зумовлять те, щоб людина подивилася на саму себе, замислилась над своєю долею. Видатний педагог підкреслює: «життя переконало: перший та відчутний результат виховання визначається у тому, щоб людина почала думати про саму себе» [8, с. 114].

Аналіз останніх досліджень та публікацій доводить, що рефлексія як чинник самовдосконалення особистості педагога, розглядається науковцями як показник переходу професійної діяльності на особистісно смисловий рівень, що є передумовою розвитку професійної культури загалом [3, с. 116].

Г. Дегтяр розглядає рефлексію як форму активного особистісного переосмислення людиною того чи того змісту своєї індивідуальної свідомості, необхідних для успішного здійснення діяльності; а також виокремлює такі механізми професійної рефлексії, як фіксація, проблематизація, самовизначення, самооцінка, мотивація [1, с. 50].

Вагомий внесок у наближення теоретичних положень про рефлексивну культуру до практики професійної діяльності педагога зроблено І. Бехом, А. Бізяєвою, Б. Вульфовим, Г. Єрмаковою, В. Кременем, Ю. Кулюткіним, С. Максименком, А. Марковою.

На думку Е. Помиткіна, пробудження в людині прагнення до самовиховання та самовдосконалення пов'язане 3 переорієнтацією особистості 3 цінностей споживання на духовні цінності: актуалізуються цінності гуманістичні (добро, благодійність), естетичні (краса, гармонія, досконалість у природі та людині), цінності самопізнання (інтроспекція, самоусвідомлення), самовдосконалення (пошук шляхів і методів самопокращення, набуття нових позитивних особистісних якостей) і цінності самореалізації (розкриття потенціалу власної особистості в служінні ближнім, Батьківщині, людству, природі) [5, с. 83]. 
Ми поділяємо думку А. Маслоу про те, що людину до розвитку заохочує прагнення до цілковитої реалізації своїх здібностей, упевненість у собі, здатність відчувати свою компетентність. Науковець вважає, що «людина часто ніби розривається між прагненням до руху вперед та прагненням до самозбереження й безпеки. 3 одного боку, вона прагне до чогось нового, а з іншого - страх перед небезпекою і чимось невідомим стримують її рух уперед» [4, с. 321].

У науковій літературі об'єктивно визначилися такі форми прагнень: наміри, потреби, неусвідомлені мотиви, установки, мрії, ідеали.

У контексті сказаного вище зрозуміло, якщо педагогом виразно усвідомлюються не лише умови, у яких він випробовує потребу, але і засоби, які розраховує він використовувати, то такі прагнення приймають характер наміру. Проте людина часто, прагнучи до чого-небудь, має смутні уявлення про те, як здійснити свою навіть виразно усвідомлену потребу. Велику роль відіграє допомога, яку можуть надати йому більш досвідчені фахівці.

Актуальність досліджуваної проблеми пояснюється також наявністю суперечностей між: необхідністю формування рефлексивної культури педагогів та недостатньою розробленістю теоретико-методологічного і змістово-методичного забезпечення цього процесу; потребою у фахівцях високого рівня рефлексивної культури і фактичним рівнем професійної компетентності педагогів; творчим характером професійної діяльності педагога і традиційною системою підготовки і навчання педагогів.

Мета статті полягає у розкритті значення мотиваційних аспектів формування рефлексивної культури у системі професійного саморозвитку педагогів.

Особистісно орієнтована модель освіти висуває до педагога високі вимоги до його особистісного, професійного розвитку комунікативних умінь і навичок, зокрема - до уміння бути активним учасником особистісно орієнтованого спілкування.

Для досягнення високих результатів у вихованні, за думкою Т. Поніманської, педагог повинен володіти певними особистісними якостями: здатність до рефлексії (усвідомлення суб'єктом того, як його сприймає суб'єкт по спілкуванню) і контролю результатів педагогічної діяльності, співробітництва 3 дитиною на засадах гуманізму, розвитку ії особистості; здатність виявляти і враховувати інтереси дітей, їхнє право на повагу, емоційно і морально підтримувати їх, прагнення до емоційної близькості у спілкуванні з ними, уміння спрямовувати його на забезпечення психологічного комфорту i своєчасного розвитку особистості; постійна налаштованість на розширення знань, самонавчання і самовиховання для вдосконалення своєї педагогічної майстерності [6, с. 134].

Ці особистісні якості складають рефлексивну, i загалом, педагогічну культуру педагогічного працівника. Під рефлексивною культурою ми розуміємо особистісноінтегральну характеристику, яка охоплює комплекс здібностей, знань та вмінь, що реалізуються через спеціальні дії, спрямовані на виявлення, оцінку, аналіз і узагальнення найбільш суттєвих ознак педагогічного процесу задля досягнення його якісних змін, а також професійне і особистісне удосконалення [7, с. 37].

Для розв'зання цих задач нами було розроблено технологію формування рефлексивної культури педагогів, яка, враховуючи здатності й особливості кожного педагога, уможливлює розвиток у них рефлексивних здібностей, умінь та знань.

Технологія формування рефлексивної культури педагогів освітніх закладів передбачає створення у системі навчання дорослих відповідних педагогічних умов: удосконалення освітнього процесу, зорієнтованого на розвиток мотивації та прагнення до саморефлексії; усвідомлення педагогами освітніх закладів значущості рефлексії та сутності рефлексивної культури; діагностування та корекція розвитку саморефлексії; залучення педагогів до рефлексивної діяльності на основі отримання і застосування рефлексивних знань (про поетапний характер здійснення рефлексивного виходу, рефлексивну культуру та способи оволодіння нею, засоби й способи рефлексивної діяльності), умінь та здібностей (усвідомлено приймати цілі й мотиви, усвідомлено входити в рефлексивну позицію, рефлексувати і планувати свою діяльність, здійснювати оцінку та самооцінку діяльності); поетапне формування рефлексивної культури засобом інтерактивних форм роботи.

В основу технології формування рефлексивної культури були покладені рекомендації І. Дичківської: 1) усвідомлювати цінність педагогічної діяльності; 2) сприяти розвитку аналітичних здібностей, які в поєднанні 3 іншими становитимуть основу педагогічної 
майстерності кожного педпрацівника; 3) вчити використовувати у практиці роботи 3 вихованцями результати сучасних наукових досліджень; 4) постійно здійснювати саморефлексію поведінки, практичної діяльності; 5) формувати потребу в постійному особистісному та професійному самовдосконаленні [2, с. 59].

Без сумніву, одним із важливих чинників забезпечення успіху технології формування рефлексивної культури, $є$ мотиваційно-цільовий етап, який передбачає усвідомлення педагогами значущості рефлексії, рефлексивної культури на основі чіткого визначення цілей особистого життя та професійно-педагогічної діяльності. Інтерес, як особистісний мотив, є для педагогів постійним спонукальним стимулом пізнання, активізує прагнення до засвоєння системи знань і розвитку системи умінь та здібностей.

Слід підкреслити значення першого етапу, який вводить педагогів до світу рефлексії, сприяе усвідомленню ними значущості рефлексивних компонентів для професійної педагогічної діяльності, але, найголовніше, визначає чітку, стійку мотивацію до саморозвитку та самовиховання.

Під мотивацією розуміємо сукупність внутрішніх та зовнішніх сил, які збуджують педагога до діяльності та надають ій певного змісту. Мотивація саморозвитку зумовлена особистісними та освітніми потребами - бажанням удосконалити власну життєдіяльність або уникнути зайвих проблем, для того, щоб стати більш розвинутою та компетентною особистістю.

Аналіз сучасної наукової літератури виявляє такі компоненти у структурі мотивації до самоосвіти: 1) самосвідомість: усвідомлення близьких і віддалених цілей, мотивів власного «я», своїх реальних і бажаних якостей, пізнавальні, когнітивні емоційно-чуттєві уявлення про себе; 2) самонавчання: соціальне визначення, усвідомлення самоосвіти як суспільного та особистого обов'язку, переконання в можливості особистого розвитку; вивчення своєї життєвої та професійної спрямованості, творчі мотиви; 3) саморозвиток: чуттєве пізнання, техніка мислення, вибір проблем та шляхів розв'язання; 4) самовиховання: самозобов'язання, самонавіювання, самоконтроль, самоаналіз, самооцінка; 5) самоорганізація: вибір джерел пізнання, форм самоосвіти, планування, організація робочого місця.

Ефективне розв'язання мотиваційних задач, на думку науковців, можливе у спеціально організованій системі професійної підготовки, яка передбачає оволодіння методами перетворення самого себе та розуміння мотивації вчинків інших, починаючи з оволодіння методами самопізнання, виявлення і вивчення власних «мотиваційних стихій».

У межах мотиваційного етапу нами пропонувались діагносту вальні інтерактивні вправи «Асоціації», «Колаж», «Моя вершина», «Квітка», «Який я педагог?»; тести «Чи Ви оптиміст?», «Чи живете Ви у згоді з собою?», «Оцінка потреб досягнення успіхів»; проективний метод «Дерево», методика визначення рівня рефлексії (О. Анісімов), методика визначення рівня самооцінки (Дембо-Рубінштейн) тощо.

Окремим блоком на мотиваційно-цільовому етапі стало використання токології - ігор та вправ, призначених для того, щоб розкрити емоційні й поведінкові особливості учасника гри.

Застосування різноманітних психолого-педагогічних ігор створювали умови, 3 одного боку, для вияву самопочуття, самовизначення та самоставлення педагогів, а з іншого, - для спостережень за реакцією та ставленням педагогів окремих груп до ситуацій та ігор, які пропонувалися.

Як домашні завдання протягом етапу педагогам надавалися питання для роздумів (рефлексивний практикум), зокрема такі: Хто Я? До чого прагну у житті? Розумію я те, що хоче від мене життя? Чи змогла я досягнути того, про що мріяла? Якщо так, то завдяки кому (чому)? Якщо ні, що (хто) завадило? Чи вмію я перемагати? Яких перемог досягла? Чи здібна я людина? Якими здібностями володію? Якими хотіла володіти? Чи цінують мене близькі мені люди? За що? Який настрій у мене переважає протягом дня? Чим він визначається? Як це впливає на успішність моєї діяльності? Що я за людина? Який у мене характер? Чи вмію я жити у ладу з самою собою? Яке уявлення у мене склалося про саму себе? Як це впливає на моє життя: на цілі, які я ставлю перед собою, яким шляхом достигаю?

Ми враховували, що процес формування рефлексивної культури має певні закономірності:

- чим більше зміст навчально-методичного матеріалу відповідає інтересам педагогів, тим вищою є їхня пізнавальна і творча активність; 
- чим частіше використовуються творчі завдання, що вимагають активної діяльності педагогів, тим інтенсивніше здійснюється зростання професійної й особистісної компетентності, зокрема, у галузі самопізнання і саморозвитку;

- чим продуктивнішою є організація практики роботи над собою, тим вищою є готовність педагогів до подальшого самовдосконалення.

Ми намагались розвинути у педагогів прагнення й потребу усвідомити свою особистісну й професійну сутність, місце і призначення в інноваційному процесі, у якому перебуває дошкільна ланка, готовність до безперервного професійного удосконалення, спрямовуючи їх на те, що сучасний педагог повинен мати право на власну думку і творчу діяльність, на їх реалізацію. При цьому акцентували увагу на тому, що процес професійно-педагогічної підготовки має здійснюватися так, щоб індивідуальна професійна сутність педагога стала однією з найважливіших.

Організовуючи дослідження, ми брали до уваги те, що успішне формування рефлексивної культури вимагає змістовної співпраці андрагогік (викладачів інститутів післядипломної педагогічної освіти та вищих закладів, керівників управлінської та методичних служб) та безпосередньо педагогів.

Відповідно до головних положень рефлексивного підходу особливість педагогічної діяльності полягає також у тому, що вона є діяльністю спільною, яка відбувається за певними законами спілкування. Викладачі, методисти та педагоги постають суб'єктами спілкування, тому пасивність одного з них призводить до зниження ефективності педагогічної діяльності. Головним показником продуктивності педагогічної діяльності можна вважати формування механізму внутрішньої саморегуляції та самоконтролю.

Основним досягненням мотиваційно-цільового етапу технології формування рефлексивної культури вважаємо практичне здійснення одного 3 принципів технології, а саме індивідуального орієнтування та педагогічної підтримки. Для нас важливо було створити умови для розкриття кожної особистості. Не менш значущим чинником слугує і те, що різноманітні вправи, тести, бесіди допомагали педагогам відчути в собі індивідуальність, характерні риси й поведінкові вияви, притаманні тільки їм.

Узагальнюючи різні погляди на проблему, підкреслимо, що прагнення до самопізнання, саморозвитку, самовиховання та самовдосконалення - важливий мотив, який спонукає педагога багато працювати і розвиватися.

При цьому відзначимо, що актуалізація в людини мотиву саморозвитку підсилює іiі мотивацію до діяльності, адже саморозвиток особистості має діяльний характер: поза іiі власною активною діяльністю, бажанням і власним зусиллям в роботі над собою її особистісне формування неможливе.

Сформувавши у собі прагнення й мотивацію до професійного саморозвитку, педагог готовий отримувати знання про те, як це зробити.

Перспективи подальших наукових розвідок стосуються рівня активності педагогів в оволодінні рефлексією, а також вияву афективних, когнітивних і процесуальних компонентів рефлексивної культури загалом.

\section{Література}

1. Дегтяр Г. О. Роль рефлексії у структурі свідомості особистості // Проблеми становлення інноваційних підходів у сучасній освіті: [зб. наук. пр.]. - Харків : Стиль-Іздат, 2004. - С. 48-52. 2. Дичківська І. М. Інноваційні педагогічні технології: [навч. посіб.] / Ілона Миколаївна Дичківська. К. : Академвидав, 2004. - 352 с. 3. Марусинець М. М. Професійна рефлексія як чинник самовдосконалення особистості майбутнього педагога / М. М. Марусинець // Педагогічний дискурс. 2010. - №8. - С.116-118. 4. Маслоу А. Мотивация и личность / А. Маслоу - СПб. : Питер, 2008. 478 с. 5. Помиткін Е. О. Психологія духовного розвитку особистості / Е. О. Помиткін. - К., 2007. 280 с. 6. Поніманська Т. І. Дошкільна педагогіка: [навчальний посібник для студентів вищих навчальних закладів] / Т. І. Поніманська. - К. : Академвидав, 2004. - 456 с. 7. Сластёнин В. А. Рефлексивная культура учителя как субъекта педагогической деятельности / В. А. Сластёнин, В. К. Елисеев // Педагогическое образование и наук. - 2005. - № 5. - С. 37-42. 8. Сухомлинський В. О. Сто порад учителеві / В. О. Сухомлинський. - К. : Рад. школа, 1988. - 304 с. 